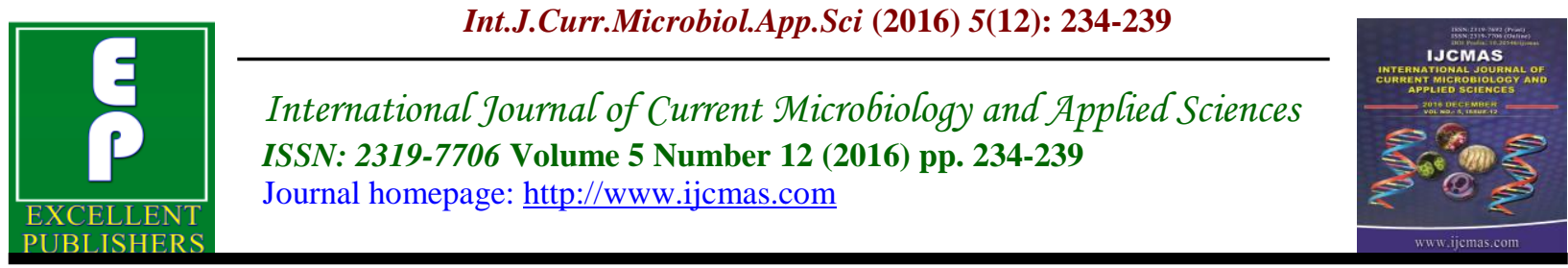

Original Research Article

http://dx.doi.org/10.20546/ijcmas.2016.512.025

\title{
Effects of Esteradiol and Testosterone on Tissue Antioxidant Status and Susceptibility to Subdiabetogenic Dose of Alloxan in Male Rats
}

\author{
Sadiq M.A. AL-Hiti* \\ College of Pharmacy, Department of Pharmacology and Toxicology, Baghdad University, Iraq \\ *Corresponding author
}

\section{A B S T R A C T}

Keywords

Estradiol,

Testosterone,

Antioxidant,

Glutathione,

Malondialdehyde,

Alloxan and antidiabetogenic.

Article Info

Accepted:

12 November 2016

Available Online:

10 December 2016
This study was designed to investigate the influence of estradiol and testosterone on the major tissues antioxidant, glutathione (GSH), and the lipid peroxidation product, malondialdehyde (MDA) in various tissues of gonadectomized rats. Also, the susceptibility of sex hormones pretreated rats to the subdiabetogenic dose of alloxan (Alx) were also studied. Castration was associated only with elevation of pancreatic GSH content compared to controls. Testosterone treatment normalized pancreatic GSH content, but decreased those of kidney and liver. Also it elevated MDA levels in almost all studied tissues. Interestingly, pretreatment of male rats with testosterone (but not estradiol) increased the susceptibility of rats to the subdiabetogenic dose of ALX, as manifested by glucosurea and mild hyperglycemia. Control rats failed to respond to ALX.

\section{Introduction}

Diabetes is a potentially still, chronic ailment with a major health concern, morbidity, mortality and prevalence increase worldwide over the past few decades (Bruce et al., 2015). Moreover it has been considered as an incurable metabolic disorders of carbohydrates, proteins and fat metabolism as a result of insulin secretion, insulin resistance, or both defects (The World Health Organization, 1999) characterized by chronic hyperglycemia (National Guidelines for Primary health care, 2013) in the blood and urine. Mostly diabetes joined with other metabolic disorders such as hypertension, dyslipidemia and a prothrombotic state it leads by the time to serious degenerative (Aizu et al., 2002) changes to multiple organs (Bresnick, 1986) in the body i.e.; heart, blood vessels, eyes, kidneys and nerves. It has been stated that global estimation of diabetes occurrence in 2014 (Global status report on noncommunicable diseases, 2014) was approximately 9\% among adults aged 18 years or older. The world health organization projects reported that the 7 th mortality cause will be diabetes of the world population in 2030 (Mathers et al., 2006). Scant studies conducted in this field to assess the defect of testosterone on tissue 
antioxidant GSH and MDA. Castrated rats estimate no detectable testosterone in rats serum which reduced all antioxidant enzymes activity and reduced the antioxidant status negatively and significantly trend to lower GSH concentration and protein thiol groups. Interestingly alloxan is an easiest reliable and most practicable drug used for chemical induction of experimental diabetes mellitus in rodents, rabbits and dogs (Usmanu et al., 2010). Additionally it transmissible induce diabetes to the litter through their parents and this may be due to alloxan induce geneticenvironmental factors attribution (Gabriel et al., 1971). It's diabetogenic action belongs to its strong selective toxicity and necrosis to insulin producing beta-cells of pancreas (Ankur et al., 2012).

\section{Material and Methods}

Adult wistar strain male rats randomly selected three groups of six animals each weighing $170-220 \mathrm{~g}$ from a breeding facility laboratory animal unite of pharmacology and toxicology dept. college of pharmacy Baghdad university were housed in hanging wire-bottomed plastic cages (6rats per cage) maintained ina constant temperature (21-25 ${ }^{0} \mathrm{C}$ ) environment with a constant $12 \mathrm{~h}$ light/12-hr dark, schedule, fed a standard laboratory rodent chow and water ad libitum for the entire experimental study period, unless otherwise specified.

The experimental protocol involves two experiments:

\section{Experiment A}

Castration was performed after animal were anaesthetized with ether. A small incision was made in the upper posterior surface of each scrotum sac, the spermatic cord then was ligated with a cat gut and the testes were removed. Then the scrotum was sutured.
A group of sham... operated male rats were used as a sham controls received an incision in the scrotumonly. Animals were left to recover from the operation for 2 weeks. Males of this research were divided into: three groups (of six rats each)

1- Controls.

2- Castrated only.

3- Castrated + testosterone (sustanon $100 \mathrm{~N} . \mathrm{V}$. organ on Oss Holland) given in 3 injections (one each other day) in adose of $10 \mathrm{mg} / 100 \mathrm{~g}$ body w.t, i.m.

At the end of the $7^{\text {th }}$ day of the experimental period, animals were anesthetized with ether, heparinized, blood samples were collected, and animals were killed by cardiac incision. Tissues (heart, liver, kidney and pancreas) homogenates (10\% w/v) were prepared in ice-cold $50 \mathrm{mM}$ Tris- $0.1 \mathrm{mM}$ EDTA buffer, $\mathrm{pH}$ 7.6.

Aliquots of their homogenates were used for the measurements of tissue GSH level by the method of moron et al., (1979) where known amounts of GSH were assayed by the same method and used for the calculation of quantities in tissues. Lipid peroxidation byproduct, malondialdehyde (MDA) level was measured using the thiobarbituric acid (TBA) reaction. The TBA reactants were calculated based on the molar absorption of $\operatorname{MDA}\left(1.56 \times 10^{5}\right)$.

Plasma levels of glucose, cholesterol and triglycerides were assayed by colorimetric assay kits (sigma Co, USA).

\section{Experiment B}

Adult male rats were used. Animals were divided into: three groups (of six animals each). 
1- Male-control-received no treatment.

2- Male- control pretreated for 6days with testosterone $(10 \mathrm{mg} / 100 \mathrm{gm}$ body wt.3 injection) as in experiment $\mathrm{A}$.

3- Male controls pretreated for 6 days with estradiol $(0.5 \mathrm{mg} / 100 \mathrm{gm}$. body wt. 3 injections) as in experiment $\mathrm{A}$.

On day 7, all groups were fasted overnight prior to the injection of a subdiabetogenic dose $(150 \mathrm{mg} / \mathrm{kg}$ body wt.) of alloxan (ALX) intraperitoneally (Kumar, 2013; Settey et al., 2013) or in a repeated low doses for several days.

Alloxan (sigma chemical Co, USA) was dissolved in normal saline (conc. $50 \mathrm{mg} / \mathrm{ml}$ ) immediately before intra peritoneal injection. Control animals received the same volume of vehicle. From our experience, a single dose of $150 \mathrm{mg} / \mathrm{kg}$ body wt. of ALX is required to induce diabetes in rats via the intra peritoneal route of injection (Kumar, 2013; Settey et al., 2013).

The diabetic state was monitored within 2448hrs. post ALX injection for glucosuria using urine test tape (glucose ${ }^{\circledR}$-Boehringer Mannheim-Germany)and hyperglycemia (colorimetric assay kit, sigma Co, USA).

\section{Data analysis}

Data were expressed as mean \pm SD. Data were analyzed by ANOVA, using a significance level of $p<0.05$. Specific group differences were determinate using student's t-test.

\section{Results and Discussion}

The efficacy of castration was confirmed in our study presented in table1, were it lowered body weight, glucose urea, cholesterol and triglycerides not significantly compared to control rats. While i.m. injection of testosterone elevates precedent values to nearly subnormal or normal.

In respect to tissue antioxidants GSH and MDA table 2 Castration showed significant increase of GSH in pancreas and not significant elevation of GSH in the heart while it slightly lowered in the kidney and the liver homogenates compared to control animals. Testosterone replacement therapy in gonadectomized male rats resulted in lowering of $\mathrm{GSH}$ in pancreas and heart to nearly normal value of control animals and significant decrease of GSH in kidney and the liver homogenates in one hand.

Table.1 General features and biochemical profile in male rats exposed to gonadectomy and hormonal therapy.

Male rats

\begin{tabular}{|l|l|l|l|}
\hline \multicolumn{1}{|c|}{ Body wt. $(\mathbf{g})$} & \multicolumn{1}{|c|}{ Control } & \multicolumn{1}{c|}{ Castration } & \multicolumn{1}{c|}{$\begin{array}{c}\text { Castration }+ \\
\text { testosterone }\end{array}$} \\
\hline Before exp. & $254 \pm 15$ & $236 \pm 20$ & $245 \pm 27$ \\
\hline End of exp. & $275 \pm 20$ & $255 \pm 29$ & $260 \pm 31$ \\
\hline Glucose $(\mathrm{ml})$ & $8.64 \pm 1.19$ & $8.50 \pm 0.90$ & $8.75 \pm 0.95$ \\
\hline Cholesterol $(\mathrm{ml})$ & $2.10 \pm 0.20$ & $2.00 \pm 0.29$ & $2.15 \pm 0.40$ \\
\hline Triglycerides $(\mathrm{ml})$ & $1.36 \pm 0.27$ & $1.25 \pm 0.25$ & $1.29 \pm 0.35$ \\
\hline
\end{tabular}

Values are expressed as mean \pm SD. $\mathrm{N}=6$ /group

Testosterone: $10 \mathrm{mg} / 100 \mathrm{~g}$ B.t (3 injections. i.m. one every other day). ${ }^{(17)}$ 
Table.2 Tissue GSH and MDA levels in male rats exposed to castration and testosterone replacement therapy.

\begin{tabular}{|l|l|l|l|}
\hline \multicolumn{1}{|c|}{$\begin{array}{c}\text { GSH } \begin{array}{c}\text { Control } \\
\text { tissue) }\end{array} \\
\text { Pancreas }\end{array}$} & \multicolumn{1}{|c|}{ Castration } & \multicolumn{1}{|c|}{$\begin{array}{c}\text { Castration }+ \\
\text { testosterone }\end{array}$} \\
\hline Heart & $1.38 \pm 0.13$ & $1.68 \pm 0.10^{*}$ & $1.35 \pm 0.25$ \\
\hline Kidney & $1.67 \pm 0.23$ & $1.74 \pm 0.30$ & $1.65 \pm 0.20$ \\
\hline Liver & $3.26 \pm 0.29$ & $3.06 \pm 0.35$ & $2.50 \pm 0.35^{*}$ \\
\hline $\begin{array}{l}\text { MDA (nmol/gm wet } \\
\text { tissue): }\end{array}$ & $7.30 \pm 0.74$ & 7.250 .86 & $5.68 \pm 0.55^{*}$ \\
\hline Pancreas & & \\
\hline Heart & $210 \pm 13$ & $200 \pm 18$ & $223 \pm 29$ \\
\hline Kidney & $257 \pm 30$ & $240 \pm 24$ & $310 \pm 32^{*}$ \\
\hline Liver & $285 \pm 24$ & $235 \pm 46$ & $415 \pm 40^{*}$ \\
\hline
\end{tabular}

Values are expressed as means \pm SD.n=6/group.

* Significantly different from control $(\mathrm{p}<0.05)$.

Table.3 Effect of estradiol and testosterone pretreatment on the susceptibility of male rats to the subdiabetogenic dose of alloxan

\begin{tabular}{|l|l|l|}
\hline \multicolumn{1}{|c|}{ Group } & $\begin{array}{c}\text { Pretreatment before alloxan } \\
\text { injection }\end{array}$ & \multicolumn{1}{|c|}{$\begin{array}{c}\text { Whole blood glucose }(\mathbf{m} \boldsymbol{\mu}) \\
\text { mmole/L }\end{array}$} \\
\hline Male control & & $7.95 \pm 0.57$ \\
\hline Male control+Testosterone & Testosterone & $11.90 \pm 0.89^{*}$ \\
\hline Male control Estradiol & Estradiol & $8.20 \pm 0.66$ \\
\hline
\end{tabular}

Values are expressed as means \pm SD. $n=6 /$ group.

Testosterone: $10 \mathrm{mg} / 100 \mathrm{~g} \mathrm{~B}$. wt. (3 injections. i.m. one every other day).

Estradiol: $0.5 \mathrm{mg} / 100 \mathrm{gm}$. B.wt. (3injections i.m.one every other day) ${ }^{(18)}$.

- Alloxan $\left(150 \mathrm{mg} / \mathrm{kg}\right.$ Body wt, i.p.): animals were fasted overnight before alloxan injection ${ }^{(15,16)}$.

- Blood samples were obtained from the tail vein 24-48 hr. post alloxan injection.

- Only these animals treated with testosterone showed positive glucose-uria using the urine test tape (glucose test ${ }^{\circledR}$-Boerhringermannhein- Germany).

In the other hand castration reduced MDA concentration in the pancreas, heart, kidney and the liver. Testosterone replacement elevates MDA concentration in pancreas and increase significantly of MDA in the heart, kidney and the liver. The susceptibility to a subdiabetogenic dose of alloxan induced rats pretreated with testosterone and estradiol hormones were seen in table 3 , in which both of them elevates blood glucose was significantly and positive glucosuria compared with normal control male rats.

In conclusion, general features and biochemical profile values were lowered in castrated male rats compared to shame 
operated animal controls. This give a view that testosterone has an effect in the homeostatic state of these biochemical and profile feature values. This was consistent with the addition of i.m. injection of testosterone which elevates the preceding values. Antioxidant status of GSH and MDA were reduced also with castration giving an evidence that a gonadectomy resulted in lowering efficacy of antioxidant enzymes and an indication towards lowering the antioxidant concentration level of GSH and MDA.

In respect to our study results this will consistence with those reported by Klapcinska (Barg et al., 2002; Tom et al., 2003). Alloxan was used as proper characteristic sub diabetogenic preferential dose to induce type one diabetes mellitus as a useful chemical agent useful in studying the pathophysiological and clinical aspect of diseases. Further studies are required to test the significance of this novel finding.

\section{References}

Aizu, Y., Oyanagi, K., Hu, J., Nakagawa, H. 2002. Degeneration of retinal neuronal processes and pigment epithelium in the early stage of the streptozotocindiabetic rats. Pub Med. Gov. US National Library of Medicine, National Institute of Health, 22(3): 161.70.

Ankur Rohilla, Shahjad, Ali. 2012. Alloxan induced diabetes: Mechanism and effects. Int. J. Res. in Pharm. and Biomed. Sci., vol 3(2).

Barg, J., Arauyo, A.S.R., Rigotto, K.V., Liesuj, S., et al. 2002. Asingl myocardial antioxidant and oxidative tress changed due to sex homones. Braz. J. Med. Bio. Res., 35: 1075-81.
Bresnick, G.W. 1986. Diabetic retinopathy viewed as aneurosensory disorder. Arch. Opthalmo., 989-990.

Bruce, W., Joshua, A., Roth, Hiep Nguyen, Louis. P., Eugene Gurrison Felber, Wesfurnback. 2015. The short-term cost effectiveness of once-daily liraglutide versus once-weekly exanatide for the term of type2 diabetes mellitus in the united states, World Health Organization, Factsheet No.312 Jan. 2015.

Chatzigeorgiou, A., Halapas, A., Kalafatakis, K., Kamper, E. 2009. The use of animal models in the study of diabetes mellitus. In vivo, 23: 245-58.

Estradiol. (Primogyn Depot-Schering AGGermany).

Gabriel, S., Pergel, Leonard, J. 1971. Levy, Morlin G. Golden. Glucose intolerance in the progeny of rats treated with single sub diabetogenic dose of alloxan. Metabolism, vol 20, Issue 4, 401-413.

Global status report on non-communicable diseases. 2014. Geneva, World Health organization.

Klapcinska, B., Jagsz, S., Sadowska-kre, Pa E., Gorski, J., Kempa, K., langfort, J. 2008. Effects of Castration and Testosterone replacement on Antioxidant defense system in the Rat left ventricle J., Physiol Sci. Adv. Pub., Doi: 10. 2170. RP 002208.

Kumar, S.S., and Mukkadan, J.K. 2013. Antidiabetic effect of oral administration of Cinnamonin wister albino rats. Bali Med. J. (BMJ), Vol 2, 3: 97-99.

Mathers, C.D., Lancar, D. 2006. Projections of global mortality and burden of disease from 2002 to 2030. PLoS med., 3(11): e 442.

Moron, M.S., Depierre, J.W., Mannervik, B. 1979. Levels of glutathione, glutathione reductase and glutathione 
S-transferaseactiveities in rat lung and liver. Biochem. Biophys. Acta, 582; 67-78.

National Guidelines for Primary health care physicians, diabetes mellitus and metabolic syndrome manegment, directorate of public Health, NonCommunicable Disease section IRAQ, 2013

Ohkawa, H., Ohishi, N., Yagi, K. 1979. Assay for lipid peroxidase in animal tissues by thiobarbituric acid reaction. Anal. Biochem., 95: 351-358.

Settey, V., Prabha, Kumar, S.S., Jose, A., Mukkadan, J.K. 2013. Astudy on antidiabetic effect of oral administration of nutmeg in wister albino rats. Asian J., Vol 1, 1: 54-57.
Testosterone. (Sustanon 100 N.V. Organon Oss Halland)

The World Health Organization. 1999-Cited by 5192 Rlated articles, part 1: Diagnosis and classification of Diabetes mellitus. Dep. Of non communicable disease surveillance. Geneva.www.whoint $>1999>$ WHO....

Tom, N.G.C., Geoy, Levng, Y.K., Ho, S.M. 2003. Androgenic regulation of oxidative stressin the rat Prostate. Involvement of $\mathrm{NAD}(\mathrm{P}) \quad \mathrm{H}$ oxidases and antioxidant defence machinery during Prostotis involution and growth, Am. J. Pothol., 163: 251322.

Usmanu Danfodiyo. 2010. Agriculture and biological, J. N. Am., 1(1):130-134.

\section{How to cite this article:}

Sadiq M.A. AL-Hiti. 2016. Effects of Esteradiol and Testosterone on Tissue Antioxidant Status and Susceptibility to Subdiabetogenic Dose of Alloxan in Male Rats. Int.J.Curr.Microbiol.App.Sci. 5(12): 234-239. doi: http://dx.doi.org/10.20546/ijcmas.2016.512.025 